\title{
Az OECD OKTATÁSPOLITIKAI TEVÉKENYSÉGÉNEK FEJLŐDÉSE
}

\author{
KÁDÁRNÉ FÜLÖP JUDIT
}

Beérkezett: 2021. szeptember 1., elfogadva: 2021. október 25.

\begin{abstract}
A tanulmány bemutatja az OECD kutatási és oktatáspolitikai tevékenységét a kezdetektől napjainkig. Elvezet a CERI megalakulásától az INES program keretében létrehozott oktatási indikátorrendszer fejlődési fázisain át az OECD által szervezett nagy mérési programokig. Betekintést nyújt a különböző OECD-programokban történő magyar részvételröl. Befejezésül felteszi a kérdést, hogy volt-e, van-e haszna a magyar oktatásügynek az OECD oktatással kapcsolatos tevékenységeiben való részvételből. Megállapítja, hogy az OECD tevékenysége sokféleképpen hat az oktatáspolitikára. Egyrészt adatokat szolgáltat az egyes országokban folyó oktatáspolitikák elemzéséhez és összehasonlításához, másrészt eszköz az oktatási rendszer lényegi kérdéseit érintő társadalmi és oktatáspolitikai viták tárgyszerűbbé tételéhez és depolitizálásához.
\end{abstract}

Kulcsszavak: OECD oktatáspolitikai tevékenysége, oktatási indikátorrendszer, magyar oktatáspolitika haszna az OECD tevékenységéből, oktatáspolitikai viták depolitizálása

The paper gives an overview of OECD's policy related activities in education from the beginnings to recent developments. Early CERI programmes aimed to find solutions to the most pressing problems of education systems by reviewing good practices across OECD countries. At the request of countries, the INES programme was established in the late 1980-ies with the aim to develop an indicator system that can describe the main characteristics of education systems, and evaluate education policies. It is shown that by standardizing international education statistics and by developing new data sources like PISA, TALIS and PIAAC, OECD has established the largest database available for education policy analysis. Working with the networks of experts from the participating countries OECD could generate meaningful debates on education both within and between countries. Together with policy makers, OECD helps countries identify systemic education problems and learn the use of statistical evidence in discussing and framing education policy.

Keywords: OECD education activities, indicators of education sysems, use of OECD activity in Hungarian education policy, statistical evidence in framing education policy

Levelező szerző: Dr. Kádár Györgyné, 1021 Budapest, Budakeszi út 27. E-mail: kadar.judit@gmail.com 


\title{
AZ OECD oktatási tevékenységének kezdetei
}

\author{
A CERI megalakulása
}

A

z OECD - amely a gazdasági növekedés és a hatékony gazdasági együttműködés céljával jött létre - szakértői jól látták, hogy az oktatásnak a szocializációban és a gazdasági fejlődésben egyaránt kiemelkedő szerepe van, és hogy az iskolarendszerek ezért legalább akkora, ha nem nagyobb figyelmet érdemelnek a hatékonyság szempontjából, mint a gazdasági tevékenységek.

Az OECD oktatással kapcsolatos tevékenységének célja kezdettől az oktatáspolitika, illetve az oktatásügy irányítóinak szakértői támogatása. Szakértői az emberi erőforrás minősége és a jövő nemzedékek szempontjából releváns kutatásokat szemlézték, és gyüjtötték az egyes országokban, régiókban látott jó gyakorlatokat. Az OECD-t létrehozó nemzetközi szerződés aláírása után létrejött igazgatási szerkezetben az oktatással kapcsolatos tevékenységek az Oktatási, Munkaügyi és Szociális Igazgatóság (Directorate for Education, Employment and Social Affairs, DEELSA) keretein belül folytak.

1968-ban a DEELSA keretei között létrehoztak egy kutatócsoportot Center for Research and Innovation (CERI) néven. A CERI a szakminisztériumokkal megegyezve önálló projekteket is indított a tagállamokat leginkább érdeklő témákban (pl. a felsőoktatás finanszírozása, egyes országcsoportok oktatási helyzetének vizsgálata, országtanulmányok készítése stb.). Az oktatáspolitikusok megnyerése, illetve igényeinek felmérése érdekében a CERI kezdettől fogva konferenciákat is szervezett oktatáspolitikusok és oktatáskutatók részvételével a közös oktatási problémák, illetve a kívánatos projektek megvitatására.

\section{A CERI korai kutatási tevékenysége}

A CERI munkatársai az 1970-es és 1980-as években elsősorban a tagállamokban felmerülő és nemzetközi szempontból is érdekes oktatási témákban végeztek kutatásokat. A CERI kutatói az országlátogatások során helybeli szakemberekkel készített interjúk és megbeszélések alapján egy-egy országtanulmányban foglalják össze megállapításaikat, javaslataikat. Ezeket jóváhagyásra visszaküldik, ami alkalmat ad a félreértések tisztázására, de az önreflexióra is. Ezt követően konferenciák, viták után elkészül a nemzetközi összefoglaló tanulmány, amelyet az OECD publikál.

$\mathrm{A} z$ első időszakban az OECD-tagállamok oktatáspolitikusait foglalkoztató és a CERI projektjeit meghatározó problémák közül kiemelkedik a bevándorló (vendégmunkás) szülők gyermekeinek integrálása az oktatási rendszerbe, a tanulók nyelvi és kulturális különbségeiből adódó pedagógiai problémák megoldásának lehetőségei az iskolákban, a nők általános munkába állása következtében az intézményes óvodai nevelés iránti növekvő igény. Emellett ezekben az évtizedekben merült fel az élethosszig tartó tanulásra való felkészítés szüksége a teljes népességben, mivel az új technológiák és a munkapiaci kereslet és kínálat gyors változása szükségképpen munkahelyek megszünésével és újfajta képzettséget igénylő új munkahelyek keletkezésével jár. Ezek a témák rendre megjelennek az 1970-es évek és a századforduló között a CERIpublikációkban. 


\title{
Az INES program első évtizede
}

\author{
Az INES program indulása
}

1988-ban az OECD-tagállamok azzal a kifejezett kéréssel fordultak az OECD Titkársághoz, hogy fejlesszenek olyan nemzetközi oktatási indikátorokat, amelyek együttese nagy vonalakban leírja az oktatási rendszereket, és amelyek összehasonlíthatóak.

A felkérésre válaszolva az OECD Titkárság elindította a CERI keretein belül az Indicators of Education Systems (INES) programot azzal a szándékkal, hogy kialakítson egy indikátor rendszert, amelynek segítségével össze lehet hasonlítani az oktatási rendszereket. Az indikátorokat egy kevés szöveget tartalmazó statisztikai kiadványban kívánták megjelentetni kifejezetten oktatáspolitikusok, illetve az oktatási rendszerek irányítói számára.

\section{Az UOE kérdöív és az Education at a Glance}

$\mathrm{Az}$ OECD első oktatásstatisztikai kiadványa Education at a Glance (Körkép az oktatásról) címmel 1992-ben jelent meg angol és francia nyelven, és 38 indikátort tartalmazott 148 oldalon. A következő, 1993-as kiadás változatlan indikátorokkal és szerkezetben, bővített adattartalommal jelent meg (OECD 1993). Ez utóbbiban már néhány indikátornál megjelennek magyar adatok is.

1994-ben az OECD az INES program keretében - az Eurostattal és az UNESCOval való megegyezés alapján - részletes módszertani útmutatót készített a tagállamok számára, egységes definíciókkal és adatértelmezésekkel segítve az adatok összehasonlíthatóságát. Az útmutató később önálló OECD-kiadványként is megjelent (OECD 2004). $\mathrm{A} z$ egyeztetések eredményeként a három nemzetközi szervezet közös oktatásstatisztikai adatgyüjtésre állt át. A kérdőív neve (UOE) az UNESCO, az OECD és az Eurostat kezdőbetűiből összeállt betűszó. A közös kérdőív bevezetése óta a különböző szervezetek azokat a statisztikákat gyüjtik külön, amelyekre csak nekik van szükségük.

A három szervezet közösen fejleszti tovább az adatgyüjtő kérdőíveket, és megosztja egymás között az adatgyüjtéssel kapcsolatos adattisztítási és ellenőrzési feladatokat. A folyamat végén az UOE adatbázist a három szervezet véglegesíti és jóváhagyja.

$\mathrm{A} z$ UNESCO által hivatalból kezelt nemzetközi oktatásstatisztikai nómenklatúra (ISCED) továbbfejlesztésében mind a három szervezet részt vesz, noha a végleges jóváhagyást továbbra is az UNESCO-közgyűlés adja (UNESCO 2011, 2013).

\section{Az indikátorfejlesztő munkacsoportoktól a PISA programig}

Egyes tagállamokban már évek óta mérték a tanulók teljesítményét mint az oktatás eredményességének mutatóját. Sok országban figyelték az összefüggést az iskolázottság és a foglalkoztatottság között. Az INES 2000. évi konferenciáján Jean E. Griffith (USA) ezekkel a szavakkal foglalta össze az indikátorok jelentőségét: „...a jól megválasztott indikátorok ereje abban rejlik, hogy a figyelmet a döntő kérdésekre irányítják. A mutatókat - indikátorokat - a részletes statisztikai adatok sokaságából azért választják ki, mert a közvélemény által fontosnak tartott, lényeges mondanivalót hordoznak a legfontosabb oktatáspolitikai kérdésekről." 
1995-ben, a (Lahtiban tartott) INES-közgyűlésen vetődött fel komolyan a gondolat, hogy a tanulási eredmények rendszeres mérésére OECD-programot kellene indítani. Ekkor már az OECD-ben folyamatban volt az első nemzetközi felnőtt kompetenciavizsgálat (IALS) Albert Tuijnman irányításával (Murray et al. 1998), ami technikai szempontból felkészülés volt egy lehetséges OECD iskolai eredményvizsgálatra.

A z INES-közgyűlést követően megvalósíthatósági tanulmány készült az OECD Titkárság részére egy háromévente szervezendő iskolai eredményvizsgálat rendszeresítéséről a 15 éves tanulók körében, amely felmérné a tanulók szövegértési, matematikai, illetve természettudományi alapműveltségét. A feladatrendszert kifejezetten a hétköznapi alapmüveltség, más szóval a civilizációs alapképességek mérésére szánták a globális gazdaság szempontjaira tekintettel, függetlenül a 15 éves tanulók iskoláiban alkalmazott tantervektől. 1997-ben jött létre a Programme for International Student Assessment (PISA) elnevezésű projekt, az első nagy volumenű önfinanszírozó OECD mérési program. A 2000-es adatfelvételt követően 2001 decemberében az OECD Londonban és Párizsban sajtótájékoztatón mutatta be az első PISA-jelentést Knowledge and Skills for Life (Életre szóló tudás és készségek) címmel (OECD 2001).

A PISA világsikerére jellemző, hogy az OECD-tagállamokon kívül egyre több oktatási rendszer kapcsolódott be a vizsgálatsorozatba. A 2018-as felmérésben már 77 oktatási rendszer adatait rögzítették.

\section{$A z$ indikátor keretrendszer}

Az INES megalapításával és az Education at a Glance elindításával az OECD valójában a népességstatisztika, az oktatási rendszerek fejlődéséből adódó finanszírozási és igazgatási problémák és az oktatáskutatási eredmények által felvetett kérdések megoldására irányuló indikátorszükségletekre reagált. Ezekhez igazította az egyre szélesebb körü adatgyűjtést és az ezekből adódó technológiai fejlesztéseit és publikációit. A hiányzó területekre önfinanszírozó projektek jöttek létre (ld. PISA, TALIS és PIAAC). Idővel azután kiderült, hogy jó lenne elvi alapon megfogalmazni azt a keretet, amelyben értelmezhetők a meglévő és a fejlesztendő indikátorok, és amelyek nagyvonalakban megmutatják az indikátorrendszer horizontális és vertikális összefüggéseit. Ehhez egy indikátormodellben állapodtak meg a tagállamok, amely modell az állapot - politikai válasz - korlátozó feltételek oktatáspolitikai logikát követi. Az indikátor keretrendszer voltaképpen az adatstratégia egyik pillére lett, amelyen belül az igények változásával bővültek az egyes cellákba illő indikátorcsoportok. Az utóbbi években az indikátor keretrendszer - egyszerűsített formában - minden EAG-kötet elején megtalálható. (Az indikátor keretrendszer leírását ld. Imre-Ostorics 2021.)

\section{A $z$ oktatási indikátorrendszer fejlődése}

\section{A népesség iskolázottságának első nemzetközi mutatói}

A II. világháború után merült fel a gondolat, hogy az ENSZ-tagállamok statisztikai rendszereit valamilyen szinten összehangolják. Az ENSZ Népesedési Bizottsága és az Amerikaközi Statisztikai Intézet 1947 és 1951 között megfogalmazta az első ajánlásokat a népesség iskolázottságának mérésére (United Nations 1954). Mindkét szervezet 
ugyanarra a három iskolázottsági ismérvre, mégpedig az írni-olvasni tudásra, az iskolai végzettség szintjére, valamint az iskolába járásra vonatkozóan ajánlott adatgyüjtést. Ez az ajánlás alapozta meg az ENSZ szakosított szervezetének az UNESCO-nak, és az Eurostatnak az oktatásstatisztikai adatgyüjtését is (Rózsa 1998). Az iskolába járók létszáma és a végzettek létszáma (illetve a népességen belüli aránya), ma is alapadata az oktatási indikátoroknak a fejlett országokban is. Az írni-olvasni tudás indikátora finomodott: az abszolút analfabétizmus helyett a fejlett országokban a funkcionális analfabéták, illetve a meghatározott szinteken olvasók arányát mérjük.

$\mathrm{A} z$ UNESCO kidolgozta az oktatási programok és végzettségek nemzetközi statisztikai besorolási rendjét, melynek első kiadását az UNESCO 1975. évi közgyülése hagyta jóvá. Ettől kezdve ezt használták a nemzeti statisztikai hivatalok a nemzetközi oktatásstatisztikai adatszolgáltatásban. Jelenleg a jelentősen kibővített harmadik, 2011ben jóváhagyott ISCED, illetve a szakmai képzésre 2013-ban jóváhagyott ISCED-F besorolást használja a nemzetközi oktatásstatisztika az egész világon.

\section{Az oktatási rendszerek kimeneti mutatói, átmenet az iskolából a munka világába}

A z oktatási rendszer kimeneti mutatói a végzettségi mutatók. A felnőtt lakosság iskolázottsági összetétele, a magasabb szinten tanulók száma és aránya, a lemorzsolódók aránya és ezek időbeni változása jelzi egy ország emberi erőforrás termelő kapacitását. Az iskolarendszerből a munkaerőpiacra való továbbhaladás relatív akadálymentességéről tájékoztatnak a végzettség és a munkaeröpiaci részvétel összefüggésének mutatói. Ilyen értelemben ezek az indikátorok az oktatás eredményességét mérik a munkaerőpiac szempontjából.

\section{A tanulás eredményessége}

A PISA vizsgálatokban 2000-től, majd 2007-től a PIAAC vizsgálatban már definiálták a kompetenciaszinteket, vagyis a tesztfeladatokat úgy állították össze, hogy a pontszámok alapján meg lehessen mondani, hogy mit jelent az a tudás, amit az adott pontszám képvisel. Ez képezi a tanulási eredmény indikátorok alapját. Ezen módszer birtokában az oktatási rendszer eredményességére, de akár a munkaerö-állomány minőségére vonatkozó becslésekre is vállalkoznak az elemzők.

\section{Az oktatás és a tanulás finanszirozásának és megtérülésének indikátorai}

$\mathrm{A} z$ OECD befektetésként tekintett az oktatásra mint humán erőforrás fejlesztésre, ami távlatilag a gazdaságot is és az egyén hasznát is szolgálja. Gazdasági irányultságából adódóan az oktatási kiadások és az oktatás és a tanulás egyéb pénzügyi vonatkozásai az első kiadás óta jelen vannak az Education at a Glance-kötetekben. Ugyanakkor az évek folyamán megsokszorozódott az oktatási ráforditás indikátorok száma. A kezdetektől megtaláljuk a pedagógusok diákokhoz viszonyított fajlagos mutatóit nemcsak mint az oktatás bumán eröforrás indikátorait, hanem a pedagógus bérekre vonatkozó indikátorokat is. A 2000-es években megjelentek a társadalmi ráforditások és hatékonyságuk, majd a társadalmi ráforditások és megtérülések összefüggéseinek indikátorai is. 
Az iskolázás befektetés az egyén szempontjából is, hiszen a tanulásba fektetett idő és munka értéke a munkaerőpiaci érvényesülésben realizálódik. A 2000-es évektől az állami kiadások mellett a tandíjak, tanulási kölcsönök, a magánszféra oktatási beruházásainak mutatói is helyet kaptak az EAG-ban. A végzettség és a relatív bérszínvonal, illetve a várható életkereset indikátorai egyfelől, másfelől az iskolázottsághoz füződő immateriális javak, mint pl. az egészség, jól-lét indikátorai ugyancsak bekerültek az indikátorok közé, jelezve, hogy mekkora befektetés értéke van a tanulásnak az egyén számára.

\section{Az oktatási körülmények mutatói}

Az oktatási körülményekre vonatkozó mutatók az INES program kezdeteitől fogva jelen vannak az Education at a Glance köteteiben. A pedagógusok diákokhoz viszonyított létszámára, életkori eloszlására, szakképzettségére vonatkozó mutatók mellett új elemként megjelentek az iskolai tanításra és tanulásra fordított pedagógus munkaidő indikátorok és a tanulói óraszámok mint a tanulási feltételek indikátorai.

A ezredforduló táján született kezdeményezés az iskolák belső világára vonatkozó indikátorok fejlesztésére. Az ISUSS (International Survey of Upper Secondary Schools) felmérést követően az évtized végére elindult az önfinanszírozó TALIS program, a pedagógusokat és iskolájukat célzó kérdőíves felméréssorozat, amely új adatforrásként lehetővé tette az iskolavezetésre, a pedagógusok attitüdjeire, módszertani kultúrájára vonatkozó indikátorok bevezetését.

\section{A tanulási eredmények szociológiai összefüggéseinek indikátorai}

Szociológiai vizsgálatok eredményei hívták fel a figyelmet az oktatási rendszerekben is megjelenő egyenlőtlenségekre és ezek társadalmi meghatározottságára (ld. pl. Ferge 1976). Az 1960-as évektől a szociológiai és a pszicholingvisztikai kutatásokban megjelent a társadalmi osztálykülönbségek továbbörökítésével kapcsolatos pszicholingvisztikai és szociálpszichológiai folyamatok vizsgálata (ld. pl. Wells et al. 1981), amit a neveléstudósok az alapfokú iskolázás reformjával és az iskolarendszer szelektivitásának csökkentésével véltek megoldhatónak. Jelentősen fejlődött a nagymintás felmérések kutatásmetodikai háttere, beleértve a mintavétel, a kérdőívszerkesztés és az elemzés statisztikai módszereit.

Az első, sok országra kiterjedő nemzetközi tudásszintmérést az 1958-ban alapított IEA Társaság kezdeményezte. Az első, matematika tantárgyi tudást mérő projektet (Husén 1967) 1970-ben egy hat tantárgyra kiterjedő felmérés követte. Az IEA vizsgálatokat nemzetközi szervezetek és alapítványok, valamint egyes kormányok önkéntes adományai és a helyi adatgyüjtés költségeit vállaló részt vevő országok finanszírozták. $\mathrm{A} z$ IEA az oktatási indikátorok fejlesztésében nagyon komoly szerepet játszott. Az IEA vizsgálatokban bukkantak fel elöször az alapvetö civilizációs képességek (literacy) indikátorai, a szövegértés, a matematikai eszköztudás és a természettudományi alapismeretek mérése révén. Ugyancsak az IEA vizsgálatok tették általánossá olyan oktatásszociológiai indikátorok bevezetését, mint például az oktatáshoz való hozzáférés mutatói, az iskolarendszer hatása a tanulási egyenlötlenségek csökkentésében, valamint a lemorzsolódási mutatók az egyes iskolafokozatok között. Az IEA vizsgálatokban jelentek meg először az iskolarendszer korai szelektivitása ellen szóló, tényekkel alá- 
támasztott érvek (Postletbwaite 1967). Az adatok rávilágítottak arra, hogy a további tanuláshoz szükséges tudásszinteket elérő tanulók hányada összesítve az iskolarendszer „tudáshozamának” tekinthető, és a magasabb alapszintet elérő tanulók hányadának növelése a tehetségek kiválasztásának „merítési bázisát” bővíti. Ez pedig csakis a kötelező alapiskolázás minőségének javítása révén érhető el azzal, hogy a tanulókat képessé tesszük az egész életen át tartó tanulásra.

\section{A gazdasági és társadalmi trendeket nyomon követö oktatási indikátorok}

$\mathrm{A} z$ oktatással kapcsolatos nemzetközi indikátorokat általában a gyermekekre, fiatalokra vontakozó helyzetjelentésként értelmezzük. Ezek az adatok azonban a jövő mérnökeiről és politikusairól is szólnak, új megvilágításba helyezve az oktatás jelentőségét gyorsan változó világunkban. Vajon a modern gazdaság, a mesterséges intelligencia megjelenése milyen kompetenciákat igényel a társadalmak tagjaitól, és milyen kompetenciák szükségesek egyáltalán a béke és a civilizáció fenntartásához? Hogyan módosulnak a tanulás és a tanítás keretei, formái, módszerei és milyen eredménnyel? Erre vonatkozóan új indikátorok is megjelennek már az újabb adatgyüjtések nyomán az Education at a Glance-ban, a PISA-felmérések és a PIAAC-felmérés jelentéseiben. Így például a PISA szövegértés vizsgálatból vannak adatok a digitális szövegértés eredményeire, vagy a problémamegoldási kompetenciára vonatkozóan. A PIAAC-felmérés tartalmaz teszteket a modern technológiai környezetben való problémamegoldásra vonatkozóan. Jövőbe mutató indikátoroknak tekinthetők például a felsőoktatás nemzetköziesedésének indikátorai mind a kibocsátó országok, mind pedig a külföldi diákokat fogadó országok szempontjából.

\section{A globális társadalom és gazdaság kompetencia- (és indikátor-)szükségletének modellje: A DeSeCo}

Viszonylag korán, 1997-ben, a PISA tervezésével körülbelül egy időben merült fel, hogy valamiféle elvi megalapozásra van szükség a mérendő tudás? ismeret? képességek? mérésére. Valami olyasmit kellene mérni, ami megmutatkozik a teljesítményben, és ami lényeges az egész életen át tartó tanulás (LLL), valamint a munkához és a közösséghez való viszonyulás szempontjából. 1998-ban svájci kezdeményezésre született egy projekt ennek a „valaminek” a meghatározására és leírására, aminek eredménye a „Definition and Selection of Key Competencies" (A kompetencia fogalma és a kulcskompetenciák), röviden DeSeCo elnevezésü tanulmány (Rychen-Salganik 2003).

A projekt vezetőinek kifejezett célja volt, hogy a PISA, és később más, az „egész életen át tartó tanulás" kategóriába tartozó OECD-felmérések tervezőinek utat mutassanak a mérések tartalmának kidolgozásához. Olyan kompetenciaterületeket azonosítottak, amelyek a globális gazdaság körülményei között megfelelnek a munkaerőpiac igényeinek, és a sikeres társadalmi beilleszkedés szempontjából is kulcsfontosságúak. A DeSeCo definíciója szerint „a kompetencia képesség a komplex feladatok adott kontextusban történő sikeres megoldására". A fogalom magában foglalja az ismeretek mobilizálását, a kognitív és gyakorlati készségeket, a szociális és magatartási komponenseket és attitüdöket, az érzelmeket és az értékeket (Vass 2009). Az autonóm cselekvéssel, az eszközök interaktív használatával és a szociálisan heterogén környezetben való müködéssel 
kapcsolatos általános kompetenciákat kulcsfontosságú kompetenciaterületként azonosították, amelyek alá besorolhatók a konkrét kompetenciák, és amelyek különböző helyzetekben a szükségletnek megfelelő konstellációkba állnak össze.

2016-ban jelentős revízió alá vették a DeSeCo-t. Ekkor már a PISA sokadik ciklusát élte, az OECD túl volt a TALIS pedagógusfelmérés második ciklusán, és a PIAACfelmérés is több hullámban zajlott.

A DeSeCo új változata DeSeCo 2.0 néven vált elfogadottá. Ebben a szerző (Rychen 2016) szerint a klímaváltozás, a túlnépesedés, az élelmiszer és a víz szükössége, a népvándorlás, a fegyveres konfliktusok elől menekülő tömegek, a mesterséges intelligencia és a tudomány fejlődésével változó munkakörök, a társadalmi feszültségek és a demokráciától való elfordulás körülményei között meg kell találni azokat a kulcskompetenciákat, amelyek szükségesek a béke és a civilizáció fenntartásához és a lehetséges boldoguláshoz. Az OECD erre vonatkozó törekvései a Strategy 2030 elnevezésü dokumentumban láttak napvilágot, amelynek gyakorlati megvalósításai megjelennek az OECD új projektjeiben.

\section{Az OECD oktatási programjának szervezeti önállósodása}

\section{Az OECD oktatási program kiválása a DEELSA igazgatóságból}

$\mathrm{A} z$ INES és az évről évre megjelenő Education at a Glance kiadvány több munkatársat foglalkoztató állandó apparátust kívánt, és a kiadvány világraszóló sikere, a nemzetközi oktatáspolitikára irányuló befolyása révén megnőtt az oktatási részleg presztízse, de ugyanakkor a költségvetési igénye is.

A PISA projekttel az oktatási programok egy új típusa is megjelent az OECD oktatási tevékenységében: az önfinanszírozó projekt. Mind az INES programhoz, mind pedig az önfenntartó projektekhez csatlakozhattak olyan államok is, amelyek nem tagjai az OECD-nek. Példa erre a World Education Indicators program, amit az OECD az UNESCO-val együttmüködve 1998-ban indított, és amely az Education at a Glance mintájára a fejlödő országokban is elindította a nemzetközi oktatásstatisztikához illeszkedő hazai adatok közlését.

A CERI mellett az INES program, a PISA program és a programokhoz csatlakozó további államok növekvő száma miatt az OECD oktatási programja kinőtte a DEELSA igazgatóság kereteit. Az OECD Tanácsa ezért önálló Oktatási Igazgatóság szervezéséről döntött 2002-ben. Az oktatási Igazgatóság neve Directorate for Education and Skills lett, utalva a PISA kiemelkedő fontosságára. Első igazgatója Barry McGaw volt. Az Oktatási Igazgatóság jelenlegi igazgatója Andreas Schleicher, aki motorja volt az INES felfutásának és a PISA program elindításának.

\section{Az Oktatási Igazgatóság irányítási szerkezete}

2007. január 1-től az OECD Tanácsa létrehozta az Oktatási Igazgatóság programjainak koordinálására és stratégiai irányítására az Oktatáspolitikai Bizottságot (Education Policy Committee, EDPC). Az Oktatáspolitikai Bizottságban általában kormányközeli tagok képviselik a tagállamokat, akik egyrészt tisztában vannak az OECD általános céljaival, oktatási tevékenységével, másrészt azzal is, hogy saját országukban mik az elvárások az OECD oktatási tevékenységére vonatkozóan. 
Az Oktatáspolitikai Bizottság fontosságát jelzi, hogy az OECD-tagállamokon kívül más államok is küldenek (küldhetnek) képviselőt „társult tag”, „résztvevő”, illetve „meghívott”, minőségben, ennek függvényében azonban tagdíj fizetésére kötelezettek. Ennek ellenére igen jelentős a bejelentkezők száma, mivel az OECD oktatáspolitikai elvei, meglátásai, oktatási adatbázisai és elemzései világszerte a legjobb minőségűek. $\mathrm{A} z$ Oktatáspolitikai Bizottság mandátumát ötévente felülvizsgálja az OECD Tanácsa.

$\mathrm{A} z$ Oktatási Igazgatóság irányítási szerkezetében a legfelső szintet képviseli az Oktatáspolitikai Bizottság, de mellette egyenrangú irányító testületként működik a kutatásra specializálódott CERI igazgató tanácsa, a PISA igazgató tanácsa és az oktatás kimeneti oldalával foglalkozó Foglalkoztatási, Munkaerőpiaci és Szociális Bizottság. Ezen szervezeti egységek indikátorfejlesztő munkáját segíti az INES tanácsadó testület (INES Advisory Group). (Melléklet 1. ábra.)

A tagállamok részéről igen sok szakértő dolgozott és dolgozik az oktatási programok különböző munkacsoportjaiban, különböző intézményekben, különböző területeken.

\section{A CERI kutatások és tanulmányok a jövőröl szólnak}

Míg az INES programok az oktatás rutinmüködésének eredményességét figyelik, addig a CERI olyan témákban végez kutatásokat, amelyek külön figyelmet érdemelnek az oktatás és a nevelés általános feladatai mellett. Ezekből van bőven, és igen gyakran az, ami megoldatlan az egyik oktatási rendszerben, régóta megoldott egy másikban. A CERI munkatársai által felvetett és kutatott jelenségek, témák mélyebb betekintést engednek az oktatás és a nevelés sokszínü és gyorsan változó világába, tematikus tanulmányaik alkalmat adnak arra, hogy a tagállamok megismerkedjenek az adott területen elfogadott vagy éppen megújult gyakorlatokkal, ezek erősségeivel és gyengéivel.

A CERI projektek közül jelentős a felsőoktatás nemzetköziesedésére vonatkozó tematikus tanulmány (OECD 2004), amelynek tanulságai elég fontosak ahhoz, hogy indikátorok segítségével kövessük a diákmobilitás trendjeit. Az erre vonatkozó kérdőív bekerült az INES adatgyüjtésbe is, 2004-től az Education at a Glance köteteiben évente megjelenik a kibocsátó és célországok kereszttáblája.

Érdemes példaképpen megemlíteni az iskoláskor előtti nevelés (Early Childhood Education and Care: ECEC) témában folyó munkát, amelynek során néhány évenként adatokat gyüjtenek a részt vevő országok kisgyermekkori nevelési és gondozási rendszeréröl (OECD 2006).

Különleges kutatás folyt és folyik kreativitás témában (Vincent-Lancrin et al. 2019), amelynek során pedagógusok és művészek együtt dolgoztak általános iskolás tanulókkal, és kitűnt, hogy a müvész látásmódja hozzá tud járulni a diákok tanulási motívációjához és kreatív gondolkodásához (Németb-Raffay 2018).

Az egykori igazgató, Jarl Bengtsson a CERI 40 éves jubileumi konferenciáján összegezve a CERI legfontosabb tevékenységeit, a következő témákat sorolta fel: esélyegyenlöség az oktatásban, az egész életen át tartó tanulás stratégiája, a kisgyermekkori nevelés és gondozás és az iskola, a sérült gyermekek integrálása az oktatási rendszerbe, innovatív iskolaigazgatás, a kreatív iskola, innováció a felsöoktatásban (Bengtsson 2008).

Ha rákeresünk a CERI címoldalára, ma a következő négy kulcstéma köré rendeződnek a programok: a jövő trendjei, innováció a tanitásban és az iskolavezetésben, komplex oktatási rendszerek kormányzása, a kutatás erōsitése és a haladás mérése. E címek alá rendezve 
találunk olyan programokat, mint a 21-dik század gyermekei, a jövő készségei: a mesterséges intelligencia megjelenésének hatása a tanulásra és a tanitásra, az oktatás jövöjét formáló trendek, az oktatás és képzés innovatív stratégiái, az oktatáskutatás megerösitése, az innováció mérése, emocionális és társas készségek mérése. Izgalmas és nehéz problémák, amelyek jövőnk, talán a túlélés kulcsai.

\section{Magyarország részvétele az INES és a CERI programokban}

\section{Magyarország részvétele a nemzetközi mérési programokban}

Magyarország 1994 óta ad adatokat az Education at a Glance évkönyvhöz. 1996-tól, csatlakozásunktól ez már kötelező feladat. Akkor még az adatszolgáltató az OM Statisztikai Osztálya volt, ma már a nemzetközi oktatásstatisztikai adatszolgáltatásnak is a KSH a felelőse, de az adatgyüjtés a többi INES programhoz hasonlóan a minisztérium nevében az Oktatási Hivatal feladata. A minisztérium és a KSH korábban is és most is közösen visel felelősséget az adatok hitelességéért és megbízhatóságáért.

A többi OECD-tagállammal együtt 1997-ben csatlakoztunk a PISA három évente ismétlődő vizsgálatsorozatához.

Amióta az OH-ban megalakult a közoktatási mérési osztály, Magyarország profeszszionális szinten képes nemcsak a nemzetközi és hazai mérések lebonyolítására, hanem az adatok feldolgozására és elemzésére is. Az osztály végzi a PISA, az IEA vizsgálatok (TIMMS, PIRLS) és a TALIS vizsgálatok hazai feladatait. Ennek köszönhető, hogy a nagy nemzetközi mérések eredményeiről 2006 óta rendszeresen készítenek magyar összefoglalót is, ezek az OH honlapján elérhetők. A mérési osztály felkészültsége tette lehetővé, hogy létrejöjjön egy hazai célokra fejlesztett tudásmonitoring rendszer is: az évente ismétlődő kompetenciamérés, ami azt is lehetővé teszi, hogy az iskolák saját munkájukat értékeljék az eredmények tükrében.

Magyar nyelvű tanulmányok készültek azokról az OECD-projektekről, amelyekben Magyarország is részt vett. A 2001-es ISUSS vizsgálatról készült OECD-jelentés (OECD 2003) fordítása mellett önálló elemzés is készült a vizsgálat magyar eredményeiröl (Imre 2005).

A 2008-ban indult TALIS program 2018-as kérdőíves felméréséről szintén készült magyar nyelvü összefoglaló a legfontosabb nemzetközi és magyar eredményekről (Balá$z s i-V a d a ́ s z$ 2019). Ebben a vizsgálatban kiválasztott iskolamintán a tanítási elképzelésekről és módszerekről, az iskolai környezet jellemzőiről kérdezték meg az iskolavezetést és a pedagógusokat.

A 2010-es években Magyarország hosszú vita után csatlakozott a felnőtt írásbeliség mérésére alakult PIAAC programhoz is, amelyet az EMMI a szakképzésért felelős minisztériummal közösen vállalt. A vizsgálat első adatfelvételében 2007-ben vettünk részt (ld. Lannert-Holb 2020), és 2021-ben részt veszünk a második ciklusban is, ennek próba-adatfelvétele jelenleg zajlik.

\section{CERI programok magyar részvétellel}

2001-ben indult tematikus program az iskoláskor előtti nevelésről (ECEC), amely kiterjedt a bölcsődei és az óvodai nevelés rendszerére, intézményeire. Magyar részről 
az OKI kapott megbízást a program kivitelezésére. A magyar szakértők által készített háttértanulmány mellett megjelent magyarul az OECD-szakértők által készített országjelentés is (Korintus et al. 2004).

2015 és 2021 között az OECD jövőbe mutató vizsgálatot indított „Kreativitásra és kritikus gondolkodásra nevelés az iskolában” címmel. A kutatás során a kiválasztott, illetve a kutatást vállaló általános iskolák egy-egy 7. osztályában egy tanár és egy művész dolgozott együtt a gyerekekkel egy féléven át. A két szakember együttmüködése termékenynek bizonyult: az elő- és utómérések tanúsága szerint a kísérletben részt vevő diákok teljesítménye és motívációja jobb volt, mint a kontrollosztályokban tanuló diákoké (Németh-Raffay 2018).

Magyarország részvételét az OECD által szervezett nemzetközi statisztikai adatgyüjtésekben, eredménymérésekben és CERI projektekben a Mellékletben található 1. táblázat mutatja be.

\section{Volt-e, van-e haszna a magyar oktatásügynek az OECD oktatási tevékenységeiben való részvételből?}

Egyértelmüen kijelenthetjük, hogy sokat lehetett tanulni az OECD-vel való együttmüködésből. Hogy eleget tanultunk-e, az más kérdés.

A pozitívumok közé sorolhatjuk, hogy az EAG némileg felkeltette a kutatók és a szakpolitikusok érdeklődését az oktatási indikátorok iránt a nemzetközi összehasonlítás lehetősége miatt. Tanulmánykötet készült az OECD INES programjáról, amelyben a szerzők ismertették az INES programot Magyarországra vontakozó elemzéspéldákkal (Imre 2003). Az OKI kiadásában 1997-től háromévente megjelent a Jelentés a közoktatásról címü többszáz oldalas, statisztikákat és elemzéseket tartalmazó kiadvány a közoktatás állapotáról, amelyben 2000-től nemzetközi adatok is helyet kaptak az OECD aktuális statisztikai kiadványaiból (Halász-Lannert 1997, 2000, 2003, 2006). A sorozat utolsó kötete ugyancsak tartalmaz OECD-adatokat (Balázs et al. 2010).

A PISA-felmérésekből 2006-tól magyar összefoglaló jelentések készültek a magyar adatok rövid elemzésével a nemzetközi adatok tükrében. Ezek nyomtatásban is megjelentek, és elektronikusan ma is hozzáférhetők az Oktatási Hivatal honlapján.

Azt nem lehet mondani, hogy az oktatáspolitikát különösebben befolyásolta volna az a kép, amit a hazai oktatásügyről látni lehetett az OECD-adatok tükrében, bár kétségtelen, hogy az OECD által felvetett problémák valamennyire visszhangra találtak a szakmai közéletben. A PISA-eredmények nem voltak rosszak, bár túlságosan jók sem, ez megnyugtatta a politikusokat. Az utóbbi években tapasztalt romló állapotok (különösen régiós viszonylatban) nem keltettek különösebb visszhangot.

Eredménynek tekinthetjük, hogy 2005-től bevezetésre került a kompetenciamérés, mégpedig megbízható módszertannal, követve az akkor már nemzetközi szabványnak számító tervezési és eszközkészítési, szervezési módszereket. Az Oktatási Hivatal mérési-értékelési feladatokkal megbízott osztálya kreatívan, precízen végezte és végzi a kompetenciamérést, és nagyon jó eszközöket fejlesztett az iskolák számára, amelyekkel saját eredményeiket össze tudják vetni más, hasonló körülmények között müködő iskolákéval. Egy időben a minisztérium figyelte az iskolák teljesítményét, és az adott viszonyokhoz képest jelentősen alulteljesítő iskolák segítségére sietett. Hogy mennyire 
volt a minisztérium vezetése elégedett az eredményekkel, illetve milyen következtetéseket vont le (ha egyáltalán) az oktatáspolitikai teendőkre nézve, azt nem lehetett tudni.

Jó kezdeményezés volt, hogy az Oktatási Minisztérium 2005-ben munkacsoportot hozott létre azzal a céllal, hogy közös fórumot biztosítson a minisztérium szakpolitikusainak, az adatok elóállítóinak, a kutatóknak és a partner szervezetek szakembereinek. A munkacsoport állandó tagjai voltak a Statisztikai Osztály és a KSH munkatársai, az OKI (később OFI) illetékes munkatársai, valamint a minisztérium területi főosztályainak delegáltjai.

A munkacsoport tájékoztatást kapott mind a hazai, mind a nemzetközi adatfejlesztési és indikátorfejlesztési munkákról, ami korábban megoldhatatlan volt a széttagoltság miatt. A munkacsoport foglalkozott az oktatás nemzetközi besorolásának, az ISCED-nek a hazai adaptációjával. Célul tűzte ki egy hazai indikátorrendszer kialakítását a rendszeres publikáció lehetőségének reményével.

Bár az oktatási indikátor munkacsoportot 2013-ban gyakorlatilag feloszlatták, egy EU-s projekt keretében az OH, az MTA KRTK Közgazdaság Tudományi Intézete és a T-Tudok Zrt. együttmüködésével sikerült létrehozni A közoktatás indikátor rendszere címü statisztikai kiadványt, amelynek három évjárata el is készült (lásd pl. Varga 2015). Emellett el tudtunk készíteni az oktatás helyzete iránt érdeklődő külföldieknek szánt kis színes statisztikai összefoglaló brossúrát angol nyelven (Kádárné 2016), amit az OH honlapjára tettek fel. Ezt már sajnos frissíteni nem lehetett.

\section{Összegzés}

$\mathrm{A} z$ OECD figyeli a gazdasági, műszaki és társadalmi trendeket és ezek várható következményeit a munkaerőpiaci és humán erőforrás igényekre. Magas szintű konferenciái a globális oktatáspolitika legfontosabb nemzetközi fórumai, kiadványainak gazdag gyüjteménye fontos forrása az oktatáspolitikai szempontból lényeges információknak.

A z INES munkacsoportjai és decentralizált projektjei által létrehozott adatbázisok és kiadványok sokféleképpen szolgálják a kormányok, a kutatók és a nagyközönség igényeit. Az indikátorrendszer úgy van összeállítva, hogy belőle következtetéseket lehet levonni az oktatási rendszerek eredményességéről, kimenetéről, feltételeiről, tágabb öszszefüggéseiről és korlátairól. Az adatbázisok nyilvánosak és ingyenesen hozzáférhetők csakúgy, mint az EAG és táblázatai. Interaktív felületek segítik az adatok elemzését, nemzetközi összehasonlítását, oktatáspolitikusoknak szánt tömör tájékoztató kiadványok, brossúrák hívják fel a figyelmet egy-egy oktatási terület sajátos helyzetére, problémáira.

A CERI országtanulmányokkal, egy-egy téma több országra kiterjedő vizsgálatával, szakértői elemzésekkel támogatást nyújt a tagállamok oktatáspolitikusainak. Összességében hozzájárul az oktatási rendszerek lényegi kérdéseit érintő társadalmi és oktatáspolitikai viták tárgyszerübbé tételéhez és depolitizálásához.

\section{IRODALOM}

BALÁzs É., Kocsis M. \& VÁGó I. (2010) Jelentés a közoktatásról. Budapest, Oktatáskutató és Fejlesztő Intézet. 
Balázsi I. \& Vadász Cs. (2019) TALIS 2018. Összefoglaló jelentés. Budapest, Oktatási Hivatal. https://www.oktatas.hu/pub_bin/dload/kozoktatas/meresek/talis/TALIS_ jelentes_2018.pdf

Bengtsson, J. (2008) OECD's Centre for Educational Research and Innovation - 1968 to 2008. Előadás, az OECD/CERI "Learning in the 21st Century: Research, Innovation and Policy" címü nemzetközi konferenciáján. 40601796.pdf OECD.org

Ferge Zs. (1976) Az iskolarendszer és az iskolai tudás társadalmi meghatározottsága. Budapest, Akadémiai Kiadó.

HalÁsz G. \& LANNERT J. (1997, 2000, 2003, 2006, 2009, szerk.) Jelentés a közoktatásról 1997, 2000, 2003, 2006, 2009. Budapest. OKI, később Oktatáskutató és Fejlesztő Intézet.

Husén, T. (1967, ed.) International Study of Achievements in Mathematics. Stockholm, Almqvist@Wiksell.

Imre A. (2003, ed.) Jelzések az oktatásról. Budapest, Országos Közoktatási Intézet.

Imre A. (2005) Az élethosszig tartó tanulás megalapozása a középfokú iskolákban. In: Imre A. (ed.) A középfokú oktatás nemzetközi tükörben. Budapest, Országos Közoktatási Intézet.

Imre A. (2005, ed.) A középfokú oktatás nemzetközi tükörben. Budapest, Országos Közoktatási Intézet.

Imre A. \& Ostorics L. (2021) Kiemelt OECD-programok és magyarországi tapasztalatai. Educatio, Vol. 30. No. 4.pp. 654-670.

KÁdÁRné Fülöp Judit (2016) Education in Hungary: Facts and Figures. Budapest, Oktatási Hivatal.

Korintus M., Villányi Gy., Mátay K. \& Badics T. (2004) Gyermekeink gondozása, nevelése. Magyarországi háttértanulmány az OECD A kisgyermekkori nevelés és gondozás szakmapolitikájá-nak tematikus vizsgálata c. programjához. Budapest, Corvinus Kiadó.

Lannert J. \& Holb É. (2020) Jó pap holtig tanul, avagy a PIAAC felnőtt írásbeliség vizsgálat tanulságai. In: Kolosi T., Szelényi I., Tóth I. György (eds) Társadalmi Riport 2020. Budapest, TÁRKI Zrt. pp. 221-243.

Murray, T. Scott, Kirsch, Irvin S., Jenkins, Lynn B. (1998, eds) Adult literacy in OECD countries: Technical report on the first International Adult Literacy Survey. U.S. Department of Education.

Németr Sz. \& Raffay E. (2018, eds) Fejleszthetö-e a tanulók kreativitása a mai magyar iskolákban? Pécsi Tudományegyetem Múvészeti Kar. https://www.t-tudok.hu/kreativpartnerseg-matematika-pilot-program-bemutato/mobile/index.html\#p=8 [Letöltve: 2021. 07. 14.]

OECD (1993) Education at a Glance. Paris, OECD.

OECD (2001) Knowledge and Skills for Life: First results from PISA 2000. Paris, OECD.

OECD (2003) Completing The Foundation For Lifelong Learning. A Survey of Upper Secondary Schools. Paris, OECD.

OECD (2004) Handbook for International Comparative Education Statistics: Concepts, Standards, Definitions and Classifications. Paris, OECD.

OECD (2004) Quality and Recognition in Higher Education: The Cross-border Challenge. Paris, OECD Publishing. https://doi.org/10.1787/9789264015104-en.

OECD (2004) Early Childhood Education and Care Policy. Country Note for Hungary. A kisgyermekkori nevelés és gondozás irányelvei. Magyarországi Országjelentés. Az OECD 
kisgyermekkori nevelés és gondozás szakmapolitikájának tematikus vizsgálata c. programjához. Ford. Addison Mónika. Budapest, Corvinus Kiadó, 2005.

OECD (2017) LSO: INES Network on Labour Market, Economic and Social Outcomes of Learning. https://www.oecd.org/education/LSO\%20brochure\%20February\%202017. pdf [Letöltve: 2021. 11.26.]

OECD (2006) Starting Strong II: Early Childhood Education and Care. Paris, OECD.

OECD/UNESCO (1999, 2001, 2002, 2005) World Education Indicators. Paris.

Postlethwaite, T. N. (1967) School Organization and Student Achievement. Stockholm, Almqvist \& Wiksell.

Rrchen, D. S. (2016) E2030 Conceptual Framework: Key Competencies For 2030 (Deseco 2.0). Working Paper Edu/Edpc(2016)23/Ann1, 9-10 November, Beijing, China.

Rychen, D. S. \& Salganik, L. H. (2003, eds) Key Competencies for a Successful Life and a Well-functioning Society. Hogrefe \& Huber Publishers.

Rózsa G. (1998) Támpontok az iskolázottsági adatok nemzetközi összehasonlításához. Statisztikai Szemle, Vol. 76. No. 2.pp. 146-165.

UNESCO (2011) International Standard Classification of Education 2011 (ISCED 2011). UNESCO Institute for Statistics. http://uis.unesco.org/sites/default/files/documents/ international-standard-classification-of-education-isced-2011-en.pdf [Letöltve: 2021. 11. 26.]

UNESCO (2013) ISCED Fields of Education and Training (ISCED-F 2013). UNESCO Institute for Statistics. http://uis.unesco.org/sites/default/files/documents/isced-fieldsof-education-and-training-2013-en.pdf [Letöltve: 2021. 11. 26.]

United Nations (1954) Handbook of Population Census Methods. New York.

VARGA J. (2015, ed.) A közoktatás indikátor rendszere. MTA KRTK Közgazdaság Tudományi Intézet.

VAss V. (2009) A kompetencia fogalmának értelmezése. https://ofi.oh.gov.hu/tudastar/hidaktantargyak-kozott/kompetencia-fogalmanak [Letöltve: 2021. 11. 26.]

Vincent-Lancrin, S., González-Sancho, C., Bouckaert, M., de Luca, F., Fernández-Barrerra, M., Jacotin, G., Urgel, J. \& Vidal, Q. (2019) Fostering Students' Creativity and Critical Thinking: What It Means in School, Educational Research and Innovation. OECD Publishing, Paris. https://doi.org/10.1787/62212c37-en

Wells, G. with conributions by Bridges, A., French P., Maclure, M., Sinha, C. \& Walkerdine, V. (1981) Learning through Interaction. The Study of Language Development. Language at Home and at School. Vol. 1. Cambridge, Cambridge University Press. 


\section{MELLÉKLET}

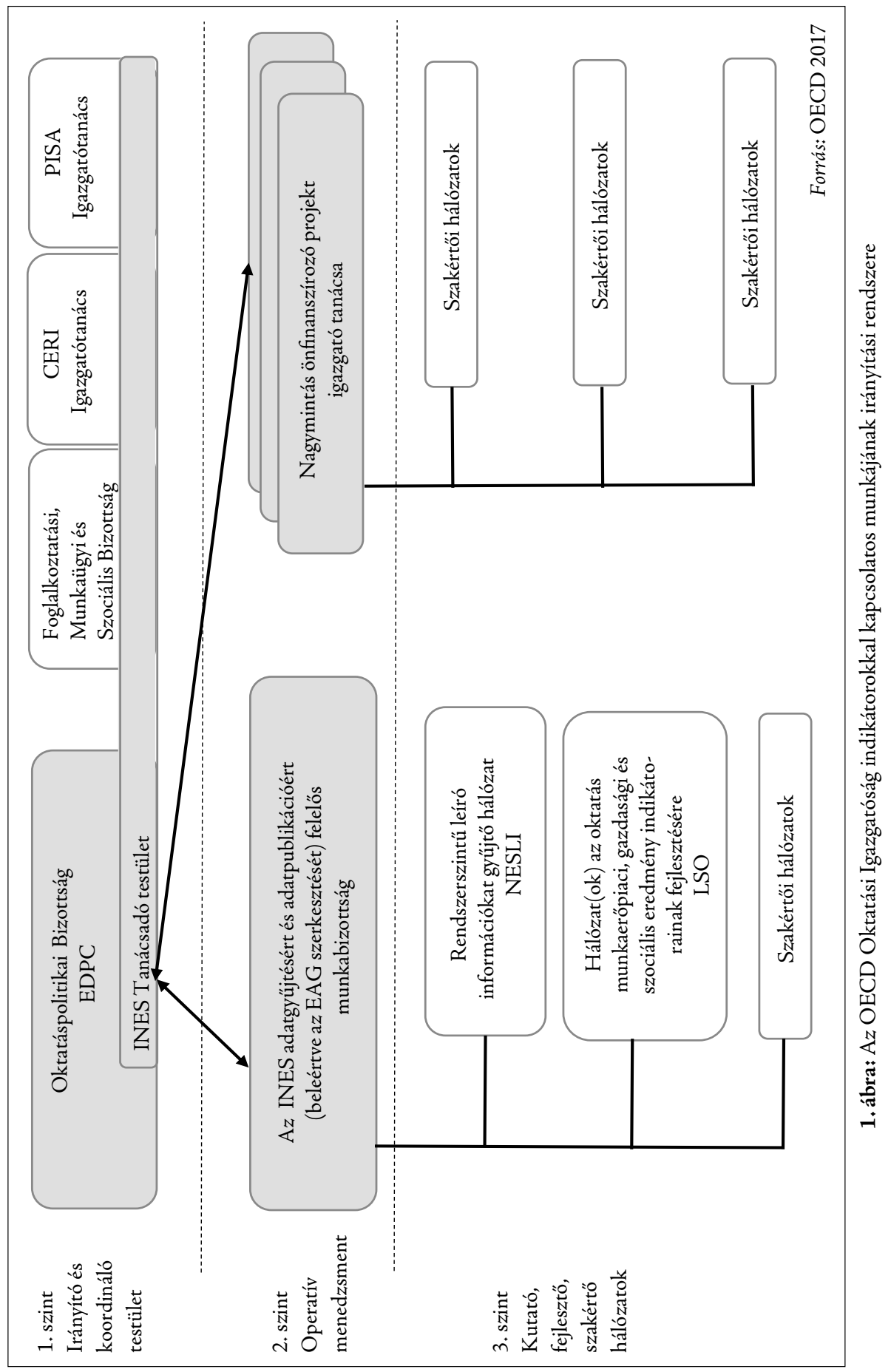


1. táblázat: Magyarország részvétele az OECD által szervezett nemzetközi statisztikai adatgyüjtésekben, eredménymérésekben és CERI projektekben

\begin{tabular}{|c|c|c|}
\hline A projekt neve & Az adatgyüjtés éve(i) & Adatszolgáltató \\
\hline \multicolumn{3}{|c|}{ Statisztikai adatgyűjtések } \\
\hline UOE-adatgyüjtés & 1994-től napjainkig & $\begin{array}{l}\text { OM Statisztikai Osztály, } \\
\text { később Oktatási Hivatal, } \\
\text { KSH }\end{array}$ \\
\hline $\begin{array}{l}\text { OECD LSO-adatgyüjtések } \\
\text { A felnőtt populáció végzettségi mutatói } \\
\text { A } 15-29 \text { éves populáció munkaerőpiaci } \\
\text { státusza és oktatásban való részvétele } \\
\text { Béradatok végzettség szerint } \\
\text { Ad hoc felmérések }\end{array}$ & 1996-tól napjainkig & $\begin{array}{l}\text { Munkaügyi és szociális } \\
\text { ügyekért felelős minisztérium } \\
\text { háttérintézménye }\end{array}$ \\
\hline $\begin{array}{l}\text { NESLI az oktatás rendszerszintü leíró } \\
\text { adatainak gyüjtése } \\
\text { Tanévenkénti tanítási idő } \\
\text { Pedagógus-óraszámok } \\
\text { Döntéshoztatali mechanizmusok }\end{array}$ & 1996-tól napjainkig & Oktatási Hivatal \\
\hline \multicolumn{3}{|c|}{ Önfinanszírozó mérési programok } \\
\hline PISA tanulói eredményvizsgálatok & $\begin{array}{l}\text { 2000, 2003, 2006, } \\
\text { 2009, 2012, 2015, } \\
\text { 2018, 2021? }\end{array}$ & $\begin{array}{l}\text { Vári Péter, Balázsi Ildikó, } \\
\text { Ostorics László }\end{array}$ \\
\hline $\begin{array}{l}\text { Középiskolák igazgatóinak kérdőíves } \\
\text { felmérése (International Study of Up- } \\
\text { per Secondary Schools, ISUSS) }\end{array}$ & $2001 / 2002$ & Imre Anna \\
\hline $\begin{array}{l}\text { Tanárok kérdőíves felmérése (Teaching } \\
\text { and Learning International Survey, } \\
\text { TALIS) }\end{array}$ & 2008,2018 & Sági Matild, Vadász Csaba \\
\hline $\begin{array}{l}\text { Felnőtt írásbeliség felmérése (Pro- } \\
\text { gramme for the International Assess- } \\
\text { ment of Adult Competencies, PIAAC) }\end{array}$ & 2006 & Zoltán Katalin \\
\hline \multicolumn{3}{|c|}{ CERI projektek } \\
\hline $\begin{array}{l}\text { Óvodai ellátás tanulmány (Early Child- } \\
\text { hood Education and Care) }\end{array}$ & $2001-2004$ & Villányi Györgyné (OKI) \\
\hline $\begin{array}{l}\text { Kreativitás ösztönzése az általános } \\
\text { iskolákban (Fostering and Assessing } \\
\text { Creativity and Critical Thinking in } \\
\text { Education) }\end{array}$ & $2015-2019$ & Németh Szilvia (T-Tudok) \\
\hline
\end{tabular}

A cikk a Creative Commons Attribution 4.0 International License (https://creativecommons.org/licenses/bync/4.0/) feltételei szerint publikált Open Access közlemény, melynek szellemében a cikk bármilyen médiumban szabadon felhasználható, megosztható és újraközölhető, feltéve, hogy az eredeti szerző és a közlés helye, illetve a CC License linkje és az esetlegesen végrehajtott módosítások feltüntetésre kerülnek. 